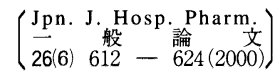

調剂支援用シロップ剂データベースの作成とその試用

長谷川健一, 駒田富佐夫*, 劑藤侑也

城西大学薬学部医薬品情報学教室†

\title{
Preparation and Trial Use of a Database of Medicated Syrups for Assistance in Drug Dispensing
}

\author{
KENICHI HASEGAWA, FUSAO KOMADA* and YUKIYA SAITOH \\ Department of Drug Informatics, Faculty of Pharmaceutical Sciences, Josai University $\dagger$
}

$\left(\begin{array}{l}\text { Received March 21, } 2000 \\ \text { Accepted September 29, } 2000\end{array}\right)$

\begin{abstract}
We prepared a database $(689 \mathrm{~KB})$ on 113 medicated syrups using Microsoft Access to quickly search information primarily concerning potential incompatibilities when dispensing medicated syrups. This database contains and allows access to data concerning 16 items such as trade names, compositions, additives, incompatibilities, and the recommended doses collected from interview forms, package inserts, in-housedocuments, and from the literature. It can also accurately calculate the pediatric dose based on the adult dose. The size of this database is $906 \mathrm{~KB}$ including the basic data of Microsoft Excel $(226 \mathrm{~KB}$ ) prepared for facilities that do not possess Microsoft Access so that the entire database can be used as a simple database that utilizes the filter function of Microsoft Excel and, with file conversion, can also be used on Windows CE and Macintosh systems. Moreover, these basic data are also available to a large number of people via the LAN and Internet when converted to FileMaker Pro 5. As a result of the use of this database, a mean of 0.9 cases of absolute incompatibilities and a mean of 1.8 cases of possible incompatibilities per item were revealed in the 113 items, and 64 items were found to contain phydroxybenzoic esters as additives, which have been suggested to have a possible side effect of inducing asthma attacks. The data on the dosage for children were missing in 26 items (about 23 $\%)$. Furthermore, we investigated the rate of prescriptions including medicated syrups at two pharmacies. The rates at pharmacy $\mathrm{A}$ and $\mathrm{B}$ were about $11 \%$ and $2 \%$, respectively. Thirty four $\%$ and $82 \%$ of the prescribed medicines included medicated syrups at pharmacy A and B. Sixty three $\%$ of the prescriptions for pediatrics patients included 3 or more medicated syrups. This database is thus considered to be useful for both preparing and evaluating prescriptions for medicated syrups, their dispensing, and also as a source for educating patients.
\end{abstract}

Key words — syrup, incompatibility, database, Microsoft Access, Web

† 埼玉県坂戸市けやき台1-1; 1-1, Keyakidai, Saka- 
ロップ剂が繁用されている．現在医療用医薬品と して,約200品目のシロップ骩が市販されており， それらを用いることが多い小児病院や，とくにシ ロップ剤処方せんの応需の多い市中薬局では, シ ロップ剂の配合調剤が関心事の一つになってい る.しかしそれらの配合変化に関する情報は, 文 献またはインタビューフォームから検索する必要 があり, 数種類処方されるシロップ剂の日常の調 剤時にそれらの情報を検索して利用することは手 間がかかり容易ではない. 現在のシロップ剤の外 来または院外調剤の実態としては，おもなシロッ プ剤の配合変化表を備えておいたり，あるいは， 単剤ずつを別の容器に秤取して患児の家族などに 交付し，使用時に組み合わせて用いるよう説明す るなどの策がとられている。しかし組み合わせ投 与にすると, 服薬時に手数をかけることからコン プライアンスが低下する恐れがある。

そこで, 薬剤師の調洬業務負担および患児家族 の服薬時の手間を減少させることを目的として, シロップ剂混合の可否を中心に, 小児薬用量計算 機能など調剤を支援するためのデータベースを Microsoft Access 97で作成した. また Local Area Network（LAN）上での使用等の広範な利用を配 虑し, FileMaker Pro 5 へのファイルの恋換を試み た.

\section{方法}

1. 使用ハードウェアおよびソフトウェア 使用ハードウェア

コンピュータ本体：DELL Inspiron 3500

CPU celeron $300 \mathrm{MHz}$,

Memory 128 MB,

Hard Disc 6.4 GB

Power Macintosh G 3

CPU Power PC G 3266

$\mathrm{MHz}$, Memory $96 \mathrm{MB}$,

Hard Disc 6.4 GB

プリンタ：FUJI XEROX Color Laser Wind 3310
使用ソフトゥェア

基本ソフト : Microsoft Windows 98 Mac OS J1-8.0

データベースソフト：Microsoft Access 97 FileMaker Pro 5

その他: Microsoft Excel 97, Netscape Navigator 4.5

2. 使用データの抽出と基本データの作成

シロップ剤では，薬効成分が同一であっても各 社で添加剤が異なる。そこで本データベースでは， 銘柄別にデータを整理収集することにした。市販 液剤757銘柄のうち, シロップ剂198銘柄を選択 し，そのうち単シロップなどの矯味・矯臭，増稠を 目的とするシロップを除いて治療目的に使われる 薬剤のみ113銘柄のデータを使用した（Table 1). 使用データは, 各医薬品の添付文書, インタ ビューフォーム，社内資料およびそれらに関する 文献 ${ }^{1-11)}$ から，シロップ剂の配合時に必要と考え られるデータを抽出した。

使用する基本データとして26項目（Table 2 ） を設定し，それらのデータが得られた製薬会社54 社からの113銘柄のシロップ剤に関するデータを 表計算ソフトMicrosoft Excel 97を用いて整理 後, これらのデータのうち, 原薬に関するデー タ, 各社の試験項目を除いて, 調剤時に必要と考 えられる22項目をリレーショナル型データベース ソフト Microsoft Access 97に取り込み, 各テーブ ルを作成した.

3. データベースの構成と検索手順

1) データベースの構成

データベースの構成を Table 3 に示す.

本データベースは16項目のテーブルと，4 項目

Table 1. 液剤データ

\begin{tabular}{lcc}
\hline & 一般名 & 銘 \\
\hline 内柄 \\
シロ液 (含ゲル) & 62 & 352 \\
ドライジロ剤 & 66 & 198 \\
合計 & 51 & 207 \\
\hline
\end{tabular}


Table 2 a. 基本データ

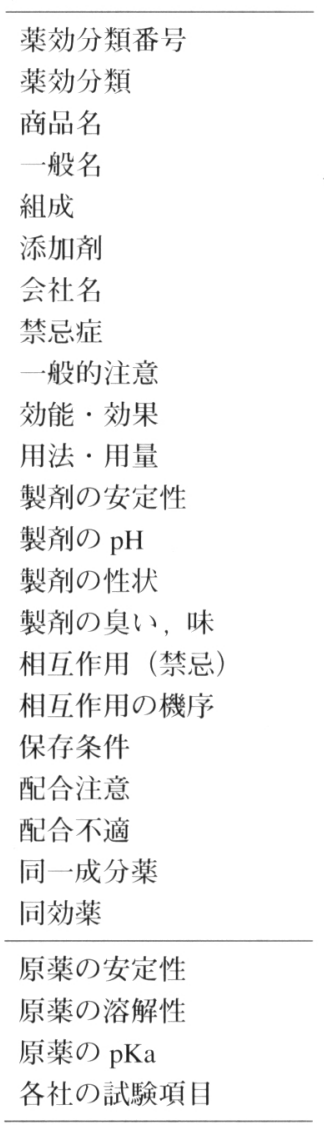

Table 2 b. フィールド定義

\begin{tabular}{l}
\hline 数字 \\
テキスト \\
テキスト \\
テキスト \\
テキスト \\
テキスト \\
テキスト \\
テキスト \\
テキスト \\
テキスト \\
テキスト \\
テキスト \\
数字 \\
テキスト \\
テキスト \\
テキスト \\
テキスト \\
テキスト \\
テキスト \\
テキスト \\
テキスト \\
テキスト \\
\hline
\end{tabular}

テキス卜
のクエリー, 4 項目のフォーム， 7 項目のマクロ によって構成した。各テーブルには，リレーショ ンを設定する際に必要な連番の登録番号（ID 番 号）をオートナンバー型で設定し，これらのデー タをフォームで利用しやすいようにクエリーを作 成した。

作成したクエリ一を基に，薬剤情報を検索する “検索フォーム”（Fig. 1 a) 作成し, 商品名入力 フォーム, 検索ボタン, 表示ボタン, 閉じるボタ ンを配置した。結果を表示する“結果フォーム”

(Fig. 1 b) には, 結果項目, 小児用量ボタン, 印刷

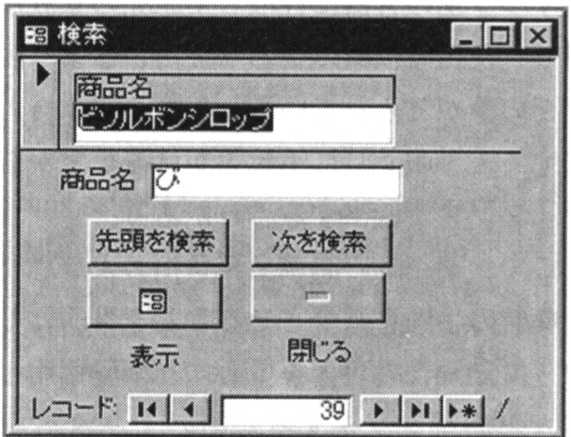

Fig. 1 a. 検索フォーム

Table 3. データベース構成

\begin{tabular}{l}
\hline テーブル \\
\hline 一般的注意 \\
一般名 \\
会社名 \\
禁忌症 \\
原薬に関するデータ \\
商品名 \\
小児用量 \\
製㓱に関するデータ \\
組成 \\
相互作用 \\
添加剤 \\
同種・同効薬 \\
配合変化 \\
保存条件 \\
薬効分類 \\
用法・用量, 効能・効果 \\
\hline
\end{tabular}


ボタン，閉じるボタンを作成した。さらに，小児薬 用量を計算する“小児用量フォーム” (Fig. 1 c) を作成した。各フォームは操作性を向上させるた
め, キーボードからの入力はできるだけ避け, 画 面上にプッシュボタンを配置し，各処理を容易に 行えるようにした，現在，多くの処方は処方せん

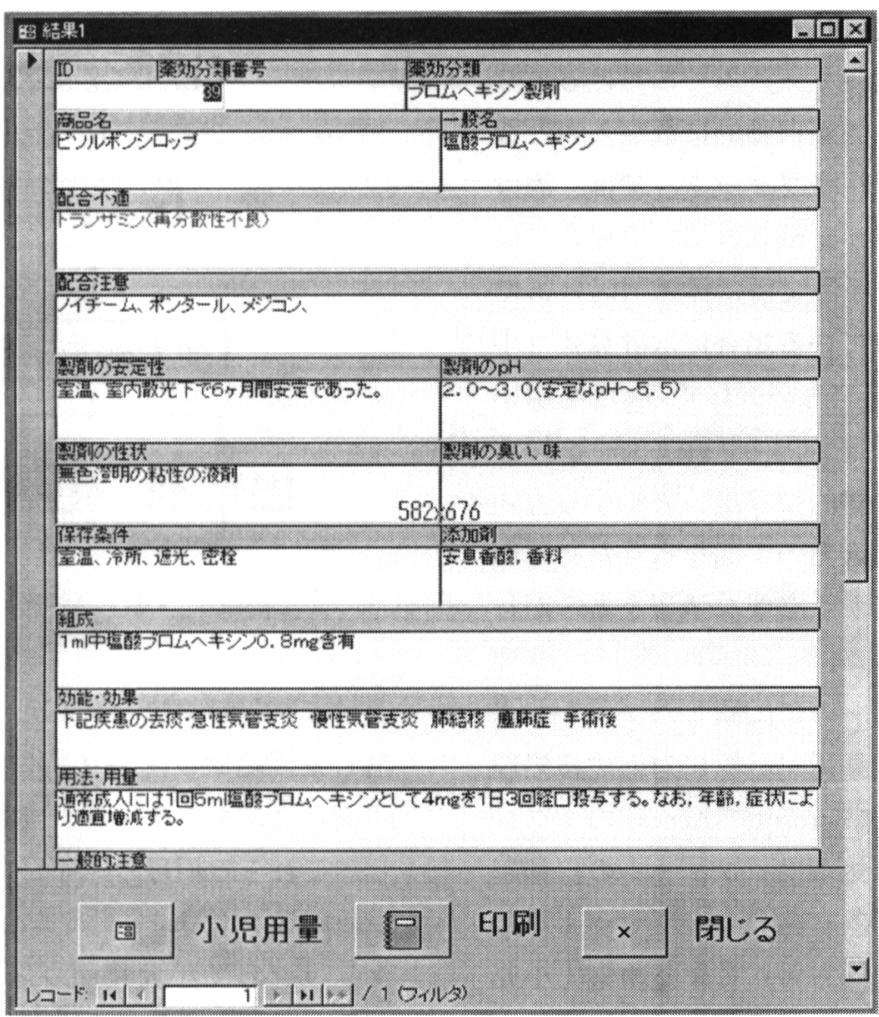

Fig. 1 b. 結果フォーム

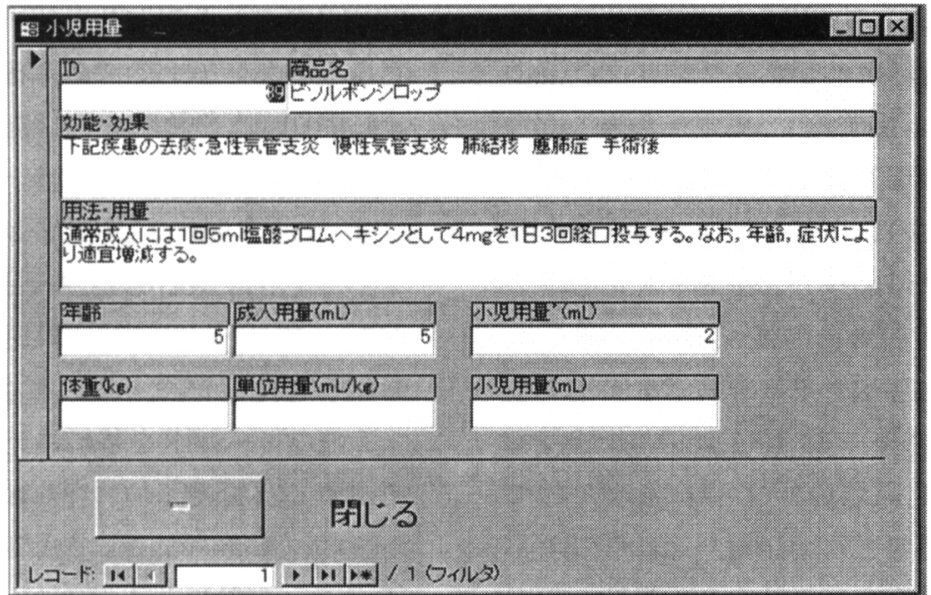

Fig. 1 c. 小巟用量フォーム 
に大部分が商品名で記載されることが多いことか ら，本データベースでは商品名によって検索する 方式にした。また，“検索フォーム”における検 索キーの入力は, 検索キー入力部分へのカーソル の移動によって自動的に日本語入力になるように した．同様に“小児用量フォーム”における各数 值の入力は, 日本語入力が自動的に数字入力とな るようにした。“小児用量フォーム”では, 添付 文書に成人薬用量のみが記載されている場合には Augsbergerの式，また添付文書に体重（kg）あた りの薬用量が記載されている場合には計算式 [小 児薬用量 $=$ 単位薬用量 $(/ \mathrm{kg}) \times$ 体重 $(\mathrm{kg})]$ を用い て，年齢，および体重を入力し Enter キーを押す ことで小児薬用量を自動的に算出, 表示する方式 にした。その際，数值入力の手間を省くため，用 法・用量のフィールドから必要な情報をあらかじ めデータとして搭載した。

医薬品名検索やフォームに配置したプッシュボ タンの表示および小児薬用量計算に対応する処理 が実行できるように, Microsoft Accessのマクロ を作成した。その主な処理は，フォームの自動起 動, フォームの終了, 医薬品名の全緅りおよび頭 文字 (平仮名, 片仮名両方可) による検索, 小児 薬用量の計算などとした。結果項目は, 見易くす るために Table 2 の項目中の原薬に関するデータ および各社の試験項目以外のデータとし, 配合不 適，禁忌症，相互作用（併用禁忌）の項目は注意 を促すために文字を赤色とした。

2) データの検索手順

データの検索手順を Fig. 2 に示す.

Microsoft Access のシロップ剂データベースの ファイルのクリックによって, 検索ボタンと終了 ボタンを示すメインフォームを自動的に呼び出 し，検索ボタンをクリックすると検索を開始する

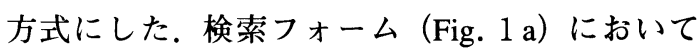
は, 商品名または商品名の頭文字 1 字の入力に よって対応する商品名を列記した。 それらの画面 に表示された医薬品の中から目的の医薬品を選択 し, 目的の薬剤を各検索ボタンを用いて指定後,

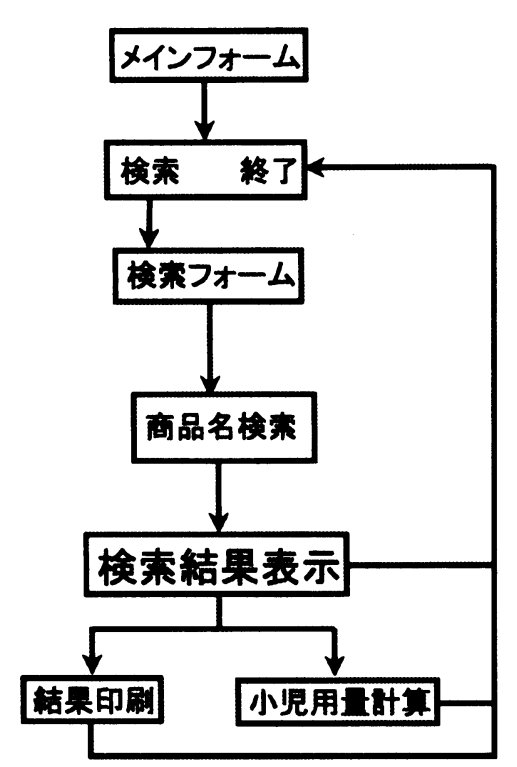

Fig. 2. 検索手順

表示ボタンのクリックにより結果フォームを呼び 出した。結果フォーム（Fig. 1b）においては, 印刷ボタンをクリックして印刷フォームを呼び出 し，これらの項目の印刷ができるようにした。 小 児薬用量を計算する場合には，小児用量ボタンを クリックして小児用量フォーム（Fig. 1 c) を呼 び出し, Augsberger 式により年齢, 成人用量, ま たは単位用量と体重の必要な情報を呼び出して, 自動的に小児薬用量を算出する形式にした。結 果，印刷，および小児用量フォームは，いずれも 閉じるボタンをクリックすることで，検索フォー ムに戻り，次の検索を容易に行えるようにした。

\section{FileMaker Pro 5 へのデータの変換}

FileMaker Pro 5 へのデータの変換に際して, フィールドは Microsoft Access 97によって構築し たデータベースの結果項目である22項目（Table 2 ）を定義した。

このフィールドを基に本データベースの一覧レ イアウト，詳細レイアウト（Fig. 3）を設定し た. Microsoft Access で構築したデータベースと 同様にレイアウト作成時には, 入力時の手間を省 くため，画面上にプッシュボタンを配置し，各処 


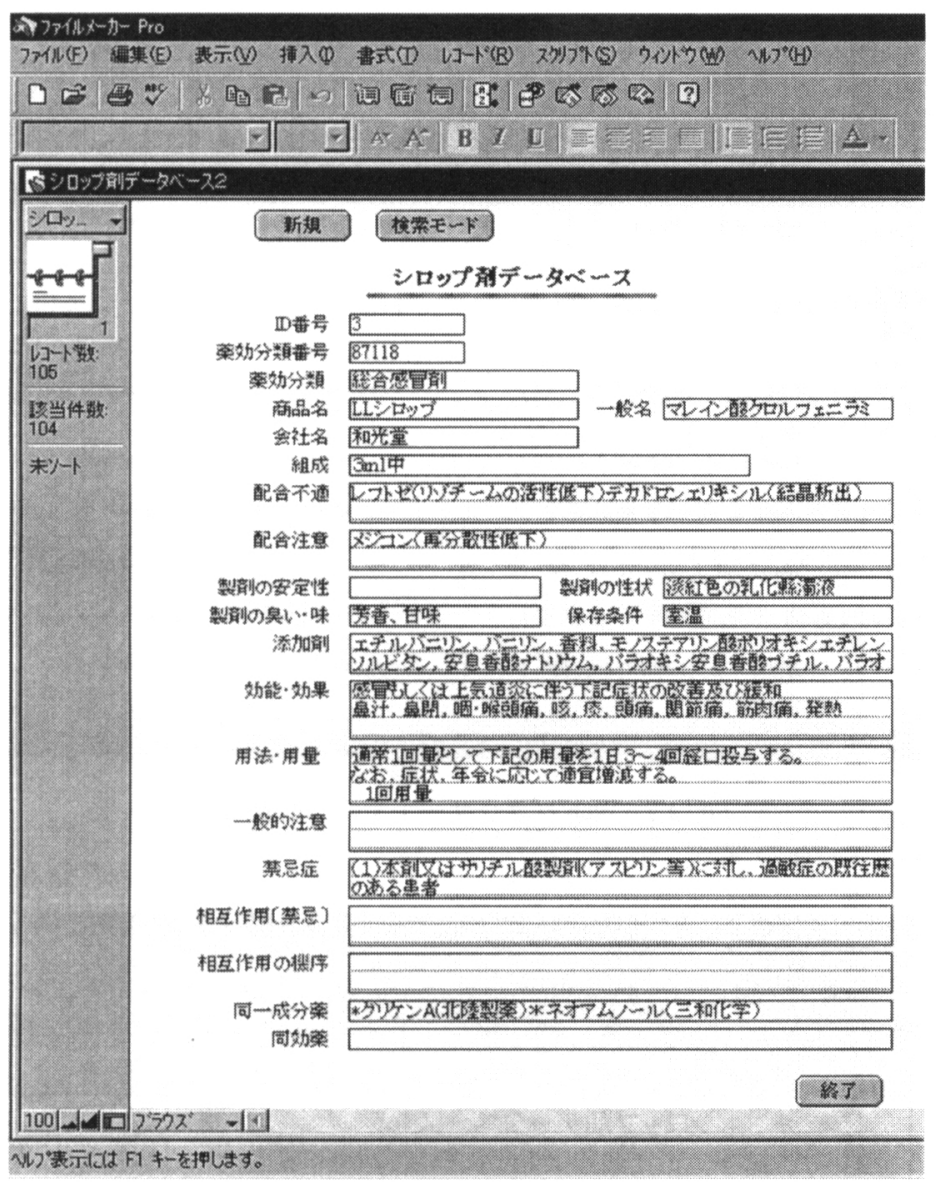

Fig. 3. FileMaker Pro 5における詳細レイアウト

理を行えるようにした。また，各入力フィールド に適した入力方法が自動的に選択されるように設 定した。データの検索は各フィールドから行える ようにした。検索方法は, 検索モード時に各項目 に目的事項の頭文字, 全文の入力後, 検索ボタン のクリックで検索可能である。また，除外の チェックボックスクリックによる人力項目以外の 検索, =,*等の各関数の使用により完全一致, ○存含む等のさまざまなタイプの検索も可能で ある。

Web 上でのデータの共有には, FileMaker Pro 5 の機能であるWebコンパニオンを用いて, Web ブラウザーでデータベースの閲覧，検索，編集な どを行えるようにした（Fig. 4 a, b). Fig. 4 a は
FileMaker Pro 5 で作成した一覧レイアウトに対応 する表示であり, Fig. 4 b は詳細レイアウト （Fig. 3 ）に対応する表示である。検索モードに 抢ける検索方法は, FileMaker Pro 5 での検索方法 とほぼ変わらないが，より簡便に検索が可能なよ うに検索条件の入力以外は, 検索タイプをプルダ ウンメニューから選択する方式となっている。レ コード編集画面で各項目の書き換え，追加が可能 であり,このレコードの編集は同一フィールドの 編集以外，同時に複数の人が編集可能である. ソート画面では，プルダウンメニューの選択によ りデータのソートが可能となっている。 


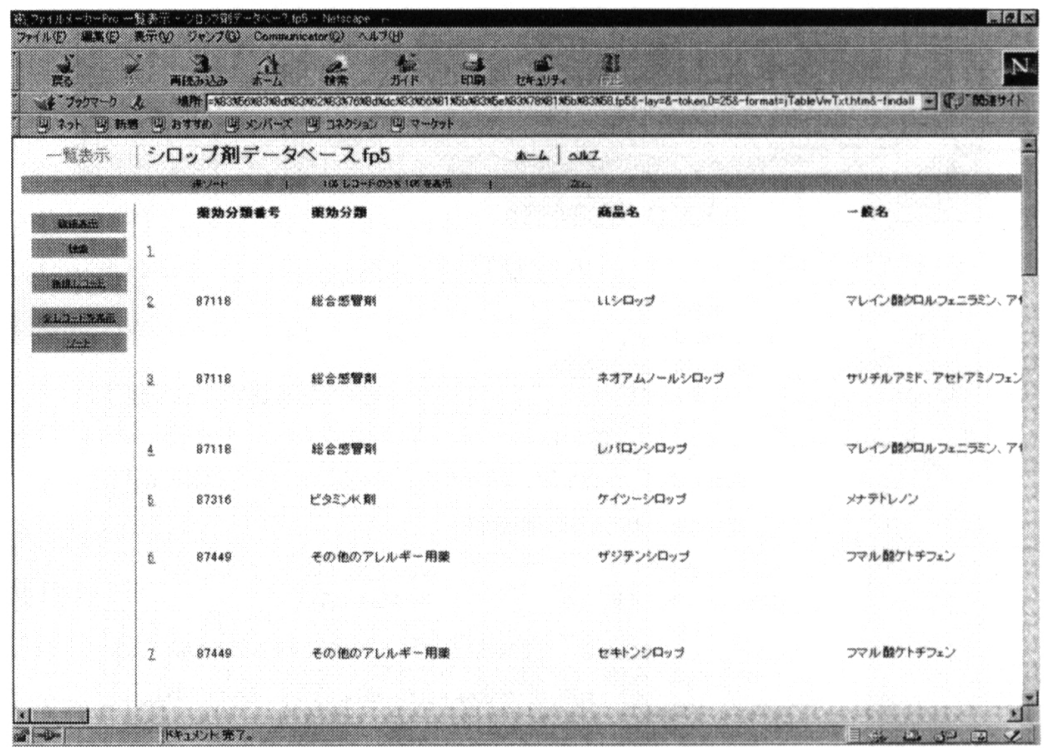

Fig. 4 a. Web ブラウザー上での一覧表示

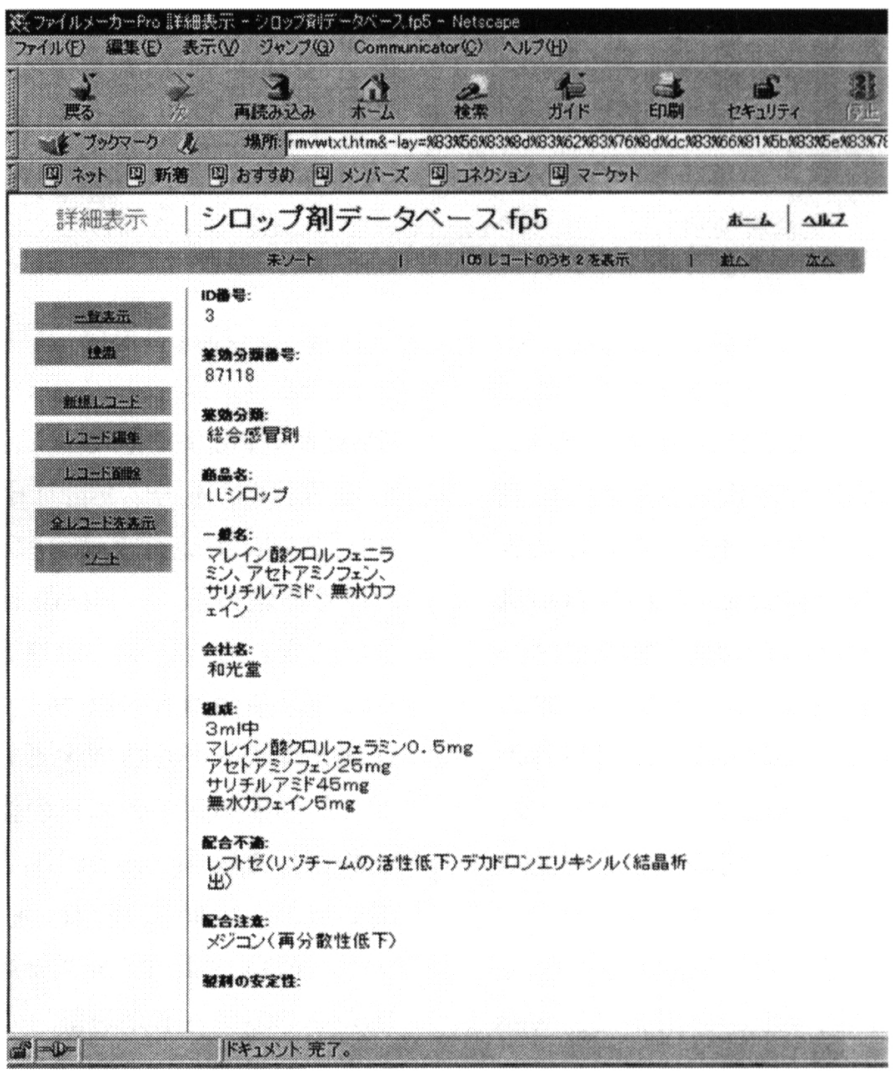

Fig. 4 b. Web ブラウザー上での詳細表示 
5. 病院，および薬局におけるシロップ剂処方の 内容調査

1) 病院

100床以下の A, B 病院, 100 500床の D 病院， 500 床以上の $\mathrm{C}, \mathrm{E}, \mathrm{F}, \mathrm{G}$ 病院, 計 7 病院に直接 問い合わせ，または院内医薬品集を用いて，院内 採用または繁用シロップ剤，および約束処方シ ロップ剂を調査した。

\section{2 ）市中薬局}

A 薬局については，平成11年11月 8 日〜13日 （6日間）に，3診療所から応需したドライシ ロップ (DS) を含めシロップ剂記載処方せん 1,571 枚について調査した。

B 薬局については, 平成11年12月 8 日〜 31日 (24日間) に，1病院（約350床）から応需した院 外処方せん 8,882 枚について調査した。

\section{6. 配合調剂に関する経済的考察}

調剤の技術料は, 調剤報酬点数表に基づいてシ ロップ配合 1 調片につき自家製剮加算として 30 点 (300円) とし, 患者に投与する容器,計量カップ, スポイト代は市販品定価の平均值として, 容器を 50円, 計量カップを22円, スポイトを15円とした。

\section{結果・考察}

今回，シロップ剤に関する情報を簡便かつ適切 に利用できるよう，薬剤師の調剤業務負担および 患児家族の服薬時の手間を減少させることを目的 として, シロップ剂混合の可否を中心に，小児薬 用量計算機能を持たせた調剤支援のためのデータ ベースを Microsoft Access 97で作成した。その 結果, 本データベースの呼び出し，検索など各操 作のアクセスタイムは，使用した DELL Inspiron 3500のハードディスク上で 1 秒とかからず瞬時に 操作が行えた.フロッピーディスク上でも 5 秒程 度であり，遅滞を感じなかった。本データベース 搭載のデータは，基本データとして作成した Microsoft Excel のデータを含めて906KBで，配布上 便利なフロッピーディスク 1 枚に収まった。この データベースは，基本データとして Microsoft Ex- cel を用いていることから, Microsoft Excelの フィルター機能を利用することによって，医薬品 名，その他に関する簡易型データベースとして検 索でき, Microsoft Access 保有施設以外での利用 に供することができた（Fig. 5 )。.また，このデー タは，桐や FileMaker Proなど他のデータベース ソフトに変換でき,さらにファイル変換により Windows CE 上での利用が可能であり PDA（Personal Digital Assistance）に搭載して使用できた.

Macintosh コンピュータを使用している病院で は，Windows版しか発売されていない Microsoft Access で構築されたデータベースを利用できな いため，本データベースを Macintosh 上で利用す る方法が求められた。そこで, Windows, Macintosh ともに利用が可能な“カード型データベー ス”に“リレーショナル型データベース”の機能 を加えたデータベースソフトである FileMaker Pro 5 に基本データをインポートした。 そのファ イル容量は $242 \mathrm{~KB}$ とさく, 基本データとあわ せても 468KBであった. 検索, 編集など各操作の アクセスタイムは，使用した Power Macintosh G3 パーソナルコンピュータのハードディスク上で 1 秒とかからず，瞬時に行えた。 フロッピーディス ク上でも 5 秒程度であり, 遅滞を感じなかった。

さらに，データベースソフトを用いていない場 合にも本データベースを利用可能にするために， Web 上でのデータの閲覧，検索に優れた機能を 持つ, FileMaker Pro 5 の Webコンパニオンを利 用してデータの共有を図った。

その結果, 一つのサーバーコンピュータを通じ てWeb ブラウザーからのデータの閲覧，検索， 編集が可能となった.

このデータの共有は院内の LAN ばかりでな く, インターネット上のホームページへの搭載が 可能であり，より多くの人々が利用できる。 とく に院内の LAN 上での使用は，調剤支援ばかりで なく，医師が処方する上での添加剤によるアレル ギーの回避, 小児薬用量の適正化など, 処方作成 支援上で医薬品の適正使用の一助となると考えら 


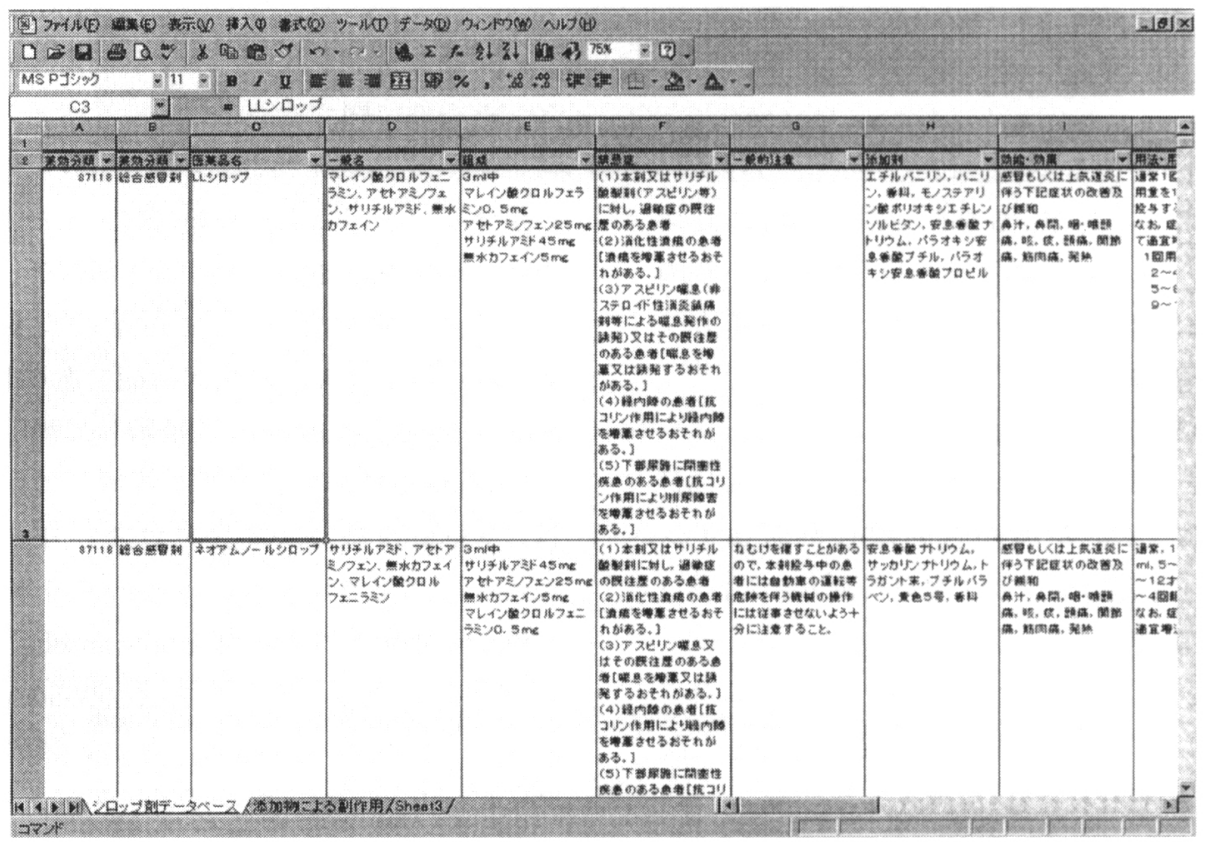

Fig. 5. Microsoft Excel 97上での簡易型データベース

れる。しかしWeb上での公開では，処理スピー ドがネットワーク回線の容量に依存するため, す ベてのネットワークに適しているとはいえない. 本大学内で使用した際, 回線が空いている時間带 ではレコードの検索, 編集, 削除などの作業は瞬 時に行え，通常の FileMaker Pro 5 上で操作して いる感覚と変わらずに操作できた。しかし，回線 が混んでいる時間帯では，それぞれの操作に数 秒〜十数秒かかり操作に遅滞を感じた。したがっ て，使用目的，利用人数，ネットワーク回線の容 量などにより，複数の FileMaker Pro 5 を用いて ファイルを共有する Local Data Access コンパニ オンを採用する方が迅速にデータ処理できる.

シロップ剂は固形製郕に比較して安定性が低 く，本データベースに用いたシロップ剂113銘柄 に関する資料では，1 銘柄あたり配合不適が平均 0.9 件, 配合注意が平均1.8件あり，他剤との配合 によって沈殿着色, $\mathrm{pH}$ や臭い・味などの物理化 学的変化を起こしやすいため注意が必要である。

本データベースによって，他剤との配合可否をは
じめ,シロップ剤に関するデータを調剤時に簡便 に検索できるようになった。しかし、本データ ベースに搭載したデータは，一定条件下に㧍ける 試験結果の引用であり，実際の患者宅に打ける保 管使用条件とは異なる。また製薬会社の試験条件 設定時に, 添付文書上の保存温度, 遮光保存の有 無などの保存条件と異なる条件で安定性試験を 行っている例もある。そこで, 薬剤交付時の一般 的服薬指導以外に, 保管方法, 細菌污染防止など について患者打よび家族への説明も重要である. また，医薬品備蓄センターなどに打ける薬局への 小分けもあり，開封後のシロップ剂の安定性に関 するデータの一層の整備が必要である。今後、本 データベースを医療機関执よび薬局に提供して， 実際の調剤上での評価を受け、データの充実, 維 持, 改善の努力を重㸚る必要がある。

製薬会社から発行されている添付文書, インタ ビューフォーム, 社内資料に記されている用語は, たとえば○○薬と○○剂, 力ゼ・風邪・風邪症候 群・感冒などや，悪心・嘔気・叶き気などの症状・ 
薬効など表現が各社で異なり, 現在では用語の標 準化が完全になされていないため，それらの資料 を用いた本データベースでは適応症, 副作用, 禁 忌などの項目から検索することは困難である．医 療用語に関する医薬規制用語集 $\left(\right.$ MedDRA/J ${ }^{12)}$ のように医薬品情報に関する用語の標準化がなさ れれば，これらの項目からのデータ検索も有用で あると考えられ, 医薬品情報データの標準化が望 まれる ${ }^{13)}$.

Table 4 に示すように添加剤による副作用発現 の恐れから，処方作成に際してパラオキシ安息香 酸エステル類 $(64 / 113$ 銘柄) によるアスピリン喘 息や，プロピレングリコール $(14 / 113$ 銘柄 $)$ によ る湿疹など添加剤による副作用の防止に配慮して いる医師もある，また，配合変化については，た とえば塩化リゾチームと亜硫酸系抗酸化剛（6/ 113銘柄）の配合により力価が低下7したり，ヒ ドロキシプロピルメチルセルロースが $30^{\circ} \mathrm{C} 7$ 日保 存で綿状の物質を生成することなどが報告されて いる4).これらから，本データベースに添加剤を 記載したことは，処方作成支援上からも有用であ る。また，搭載した製郕の安定性，製剤の $\mathrm{pH} の$ データは，製薬会社が試験公表していない配合に ついて改めて検討する際にも便利であると考えら れる.製剤の性状，臭い，味の記載は，配合に よって製剤の外観，臭い，味の変化を予測するこ とを支援できる。さらに保存条件，同種・同効薬 の記載は，一般的に安定性の低い液剤を調剤する 場合の患者指導，配合変化の記載に該当した配合 の疑義照会など，処方鑑査，調剤，患者指導時に
有用である。

小児薬用量は，処方鑑查，調剤時に慎重な判断 が必要である．本データベースに用いた113銘柄 のシロップ剂の添付文書，インタビューフォーム によると，小児薬用量が記載されていた医薬品は 年歯層別の記載49銘柄（約43\%），体重あたりの 記載は46銘柄（約41\%）（年齢層別と体重あたり の記載の両方の記載例もある)，小児薬用量の一 括記載は 4 銘柄（約 $4 \% ） ， 小$ 児薬用量の未記載 が26銘柄（約 $23 \% ）$ 認められた。そこで本データ ベースでは Augsberger 式と単位薬用量から容易 に換算できるようにした。しかし，患児体重から 小児薬用量を求めると成人薬用量を超えてしまう 例が少なくなく，データベース上で計算值が成人 量に達するときに警告を表示するなど改善が必要 と考える.

以上，本データベースを作成したことにより， 添付文書からは得ることのできない，シロップ剂 に関する情報を簡便に検索できるようになった。 また，製剤に関する情報の搭載により，調剤時に あらかじめ配合変化の予測が可能となった。さら に，添加剤に関する情報を搭載したことにより， 添加剤に起因する副作用を防止することができ， 医師の処方作成上においても有用なデータベース であることが示唆された。

さらに，本データベースを現段階でいくつかの 施設で試用した結果，結果フォームの階層を増や して表示内容を改善することによる認識性の向 上，処方入力フォームの作成による多剤併用時の データの検索の簡便化が望まれた。また，ドライ

Table 4. 添加剈により生じる副作用

\begin{tabular}{|c|c|c|}
\hline 添加剤名 & 副作用 & $\begin{array}{c}\text { 113銘柄 } \\
\text { 中の数 }\end{array}$ \\
\hline パラオキシ安息香酸エステル類 & アレルギー性接触皮膚炎, アスピリン喘息誘発 & 64 \\
\hline 安息香酸ナトリウム & アスピリン喘息発作誘発 & 35 \\
\hline プロピレングリコール & 湿疹 & 14 \\
\hline 亜硫酸塩 & 喘息発作誘発 & 6 \\
\hline HCO-60（硬化ヒマシ油） & アナフィラキシーショック & 6 \\
\hline 黄色 4 号 (タートラジン) & 蕁麻疹，喘息発作誘発 & 5 \\
\hline
\end{tabular}


シロップ配合時のデータの追加, 処方鑑査ジステ ム, バーコードリーダーによる液剤調剤監査シス テム, 保険薬局で用いられているレセプト用シス テムへの本データベースの組込み等が望まれ, 現 在検討中である.

病院，および薬局におけるシロップ剂処方内容 の調査結果を以下に示す.

病院における取り扱いシロップ剤の配合変化に 関する調查結果, ならびに採用, および繁用シ ロップ剂間で配合変化が起きる率を銘柄あたりで まとめたものを Table 5 に示す.

以上の調查結果より, シロップ剂が繁用される ことが多いと予測される小児医院 (A 病院) の繁 用シロップ剤は，1 銘柄の組み合わせを除き配合 上問題ないように採用されていた。これはシロッ プの配合調剤によって, 服薬, 操作時の手間によ るコンプライアンスの低下を防止する上で非常に 有用であると考えられる.

逆に 7 病院中, 3 病院 $(\mathrm{D}$ 病院, $\mathrm{E}$ 病院, F 病 院）で採用されているシロップ剤は，アスベリン

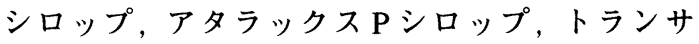
ミンシロップ, ビソルボン液, ペリアクチンシ ロップ, ポンタールシロップ, メジコンシロップ 等の同一処方せん中に処方されることが予想され るシロップ剤間で配合変化が多く，医師の配合処 方作成を考慮した, 薬烱採用時の配合変化に対す る検討も必要であると考えられる。

また，院内約束処方中にも配合注意の薬剤であ る “アスベリンシロップ”と“ペリアクチンシロッ プ”が配合されていた。これがシロップ剤配合に 関する情報量の少なさに起因するものか, 病院薬

Table 5. 病院における採用，および繁用シロップ 剂調査結果

\begin{tabular}{c|rrr}
\hline 病院 & $\begin{array}{c}\text { 採用および繁用 } \\
\text { シロップ都品目 }\end{array}$ & 配合不適(\%) & 配合注意(\%) \\
\hline A & 9 & 11 & 0 \\
B & 5 & 0 & 0 \\
C & 10 & 0 & 20 \\
D & 7 & 43 & 57 \\
E & 13 & 38 & 69 \\
F & 24 & 100 & 67 \\
G & 11 & 9 & 9 \\
\hline
\end{tabular}

片部の経験上問題ないと判断したのかは明らかで はないが，これらのシロップ剤の配合による配合 変化は再分散性の不良であるため, 患者交付時に は “用時振盪”など，特に服用時の注意を徹底す ることが必要である。

以上, 本データベースの試用により，シロップ 剤の配合調剤を可能とするためには, 薬剤採用時 から採用薬㘊間で配合変化の少ない薬剤採用が必 要であることが示唆された。

次に，市中薬局における処方せん調査の結果を 各 Table 6,7 に示す.

Table 6 は市中の院外処方せん応需薬局 $\mathrm{A}$, な らびに B の応需処方せん中に記載されていた薬 剤を組み合わせることにより起こりうる配合変化 である。

市中薬局における調查結果では，A 薬局での使 用シロップ剂間で, 多数の配合変化が予測され た.しかし, 実際の発行処方せん上では, 配合変 化が起こらないよう，ニポラジンシロップ投与時 には配合不適の薬片であるムコソルバンシロップ の代わりに，同効薬であるムコダインシロップを 投与する等の医師の工夫が見られた。

Table 7 は院外処方せん応需薬局における, 診 療科別のシロップ剂処方せん受付枚数, およびこ れらの処方せん中におけるシロップ剤の配合調剤 が可能な処方せん枚数の集計結果である.

シロップ剤の処方率は $\mathrm{A}$ 薬局で約 $11 \%, \mathrm{~B}$ 薬 局で約 $2 \%$ あり，それらのうちA薬局で約 $34 \%$ ， B 薬局で約 $82 \%$ が配合可能であることが明 らかとなった。 また，耳當科と比較して小児科の 処方せんに配合可能なシロップ剂処方が多いこと が認められた。

本調查によりドライシロップ殽の配合が $\mathrm{A}$ 薬 局でシロップ剤処方全体の約 $38 \%$, B 薬局で約 58\%と多く，このシロップ剂データベースにドラ イシロップ剤配合のデータの追加の必要性を認識 した。そこで現在，ドライシロップ剤配合に関す るデータベースを作成中である.

また，小児科のシロップ剂処方に 3 骭以上の処 
Table 6. 市中薬局におけるシロップ剂調查結果

\begin{tabular}{|c|c|c|}
\hline \multicolumn{3}{|l|}{ A藻局 } \\
\hline 商品名 & 配合不英 & 配合注意 \\
\hline $\begin{array}{l}\text { フスコデシロップ } \\
\text { ムコダインシロップ } \\
\text { ニポラジンシロップ } \\
\text { ポンタールシロップ } \\
\text { レフトーゼシロップ } \\
\text { ムコソルバンシロップ } \\
\text { アタラックスPシロップ }\end{array}$ & $\begin{array}{l}\text { レフトーゼシロップ(棅晹) } \\
\text { アタラックスP } \\
\text { ムコソルバン } \\
\text { アタラックスP、フスコデ } \\
\text { レフトーゼ }\end{array}$ & $\begin{array}{l}\text { ポンタール(7日まで用時振盕) } \\
\text { ムコソルバン } \\
\text { ポンタール }\end{array}$ \\
\hline \multicolumn{3}{|l|}{ B菜局 } \\
\hline 商品名 & 豆合不道 & 配合注意 \\
\hline $\begin{array}{l}\text { インクレミンシロップ } \\
\text { ザシテンシロップ } \\
\text { デパケンシロップ } \\
\text { ファンギソンシロップ } \\
\text { フェノハールエリキシル } \\
\text { フスタギン浓 } \\
\text { ヘソアクチンシロップ } \\
\text { ポララシンシロップ } \\
\text { ポンタールシロップ } \\
\text { ムコソルバンシロップ } \\
\text { メプチンシロップ } \\
\text { レフトーセ }\end{array}$ & $\begin{array}{l}\text { フエノバールエリキシル(再分荍 } \\
\text { 性不良、ゲル状)、レフトーゼ } \\
\text { (再分数性不良、ゲル状) }\end{array}$ & $\begin{array}{l}\text { サジテン、ペリアクチン、ポララミ } \\
\text { ン.ムコソルパン } \\
\text { アスベリン、ポンタール }\end{array}$ \\
\hline
\end{tabular}

Table 7. 処方せん集計結果

\begin{tabular}{|c|c|c|c|}
\hline 応需菲局 & 酊瘄科 & シロップ敖妋方枚数(\%) & シロップ剂配合可能枚数(\%) \\
\hline \multirow[t]{2}{*}{$\bar{A}$} & $\begin{array}{l}\text { 耳科 } \\
\text { その他 }\end{array}$ & $\begin{array}{l}99 \\
75\end{array}$ & $\begin{array}{r}55(55.6) \\
4(5.3)\end{array}$ \\
\hline & at & $174(11.1)$ & $59(33.9)$ \\
\hline \multirow[t]{3}{*}{ B } & $\begin{array}{l}\text { 小肾科 } \\
\text { 耳留科 }\end{array}$ & $\begin{array}{r}190 \\
17\end{array}$ & $\begin{array}{r}162(85.3) \\
10(58.8)\end{array}$ \\
\hline & その他 & 4 & $0 \quad(0)$ \\
\hline & 壾 & $211(2.4)$ & $\overline{172(81.5)}$ \\
\hline
\end{tabular}

方が $63 \%$ ，多剤併用が多いことが明らかとな り，小児科からの院外処方せん応需が多い市中薬 局で，本データベースはより有用であることを認 識した。

配合調剤に関する経済的考察を以下に示す。 容器代等を薬局が負担する時，本データベース を使用し，単骺投与を配合投与に変更すること で, 薬局 A（シロップ剂を含む処方せん受付枚 数：174枚/月）では，1月当たり42,000円前後, 薬局 B（シロップ剂を含む処方せん受付枚数： 211枚/月）では，1月当たり77,000円前後の収入
増があることが認められた，つまり，受付処方せ ん枚数によっても異なるが，シロップ剂処方せん の受付枚数が多く，さらに，1処方あたりのシ ロップ剂数が多いほど，シロップ剂の配合により 病院・薬局の容器・カップ・スポイト代の負担が 減少できるのみならず，“自家製剤加算” の加点 により薬局の収入が大きくなるが，患者側の負担 は“自家製剂加算”が加算されるため大きくな る。しかし，組み合わせ投与による服薬の手間か ら，服薬時のコンプライアンスが低下する恐れを 考慮すると，配合調姷は“病院・薬局”, “患者” 
の両側面からみても意義があると考えられる.

謝辞 本データベース作成にあたって，資料を提 供していただいた各製薬会社関係各位，作成中に 種々ご示唆ご協力下さった日本大学医学部附属板橋 病院薬剤部の医薬品情報室の皆様, 採用および繁用 シロップ剂，処方せん調査に協力していただいた病 院薬凨部の皆様，ならびに市中薬局の皆様に深く感 謝いたします。

本研究の一部は，平成10年度，および11年度，厚 生省医薬安全局総合研究事業（医薬品適正使用のた めの情報提供のあり方に関する研究；1014101）の援 助によるものである.

\section{引用文献}

1) 高杉益充, 宮田一好, 水口和生, 須藤真琴, 病 院薬学, 5, 169-175 (1979).

2) 大城進, 外間惟夫, 藤本勝喜, 病院薬学, 13, 327-331 (1987).

3) 外間惟夫, 大城進, 藤本勝喜, 病院薬学, 13, 396-400 (1987).

4) 外間惟夫, 大城進, 藤本勝喜, 病院薬学, 16,
37-44 (1990).

5) 若松弘文, 本屋敏郎, 石橋丸應, 病院薬学, 18, 674-681 (1992).

6）西垣員男，市場みすず，大和田恵子，武信貞 夫，君田富美子，千賀慶太郎，病院薬学， 5 , 118-122 (1979).

7）鈴木時紀，伊藤譲，山田喜広，吉田知由，二橋 純一, 川影逸郎, 藤井喜一郎, 病院薬学, 12, 4-8 (1986).

8）尾家重治，松岡加津子，高濱清子，足立タッ 子, 神谷晃、薬骫学, 54, 175-179 (1994).

9）林弘祐，横地義郎，北澤正康，須原清治，北澤 式文, 病院薬学, 11, 407-413 (1985).

10）鈴木時紀，柴田悠喜，吉田知由，鈴木吉成，山 田喜広，姉崎健，川影逸郎，藤井喜一郎，病院 薬学, 17, 59-64 (1991).

11) 甲斐順子, 瀬尾量, 児玉裕文, 橋本強, 鶴岡道 雄, 病院薬学, 10, 384-387 (1984).

12）“医燎用語規制用唔集 (MedDRA/J) バージョン 2.1”，日本公定書協会。

13) 藤井俊志, 月刊薬事, 40, 2501-2503 (1998). 